\section{Why does de-radicalization seem a utopia? Evaluation on "Children of the Country" program}

\author{
Hafid Algristian, Dian Dakwatul \\ Choiriya, Diaz Syafrie Abdillah, \\ Athiyatul Ulya, Hafizh Auliyan Sodali, \\ Akbar Reza Muhammad, Handayani \\ Faculty of Medicine, Universitas \\ Nahdlatul Ulama Surabaya, Indonesia
}

\begin{abstract}
Children and adolescents are groups that are vulnerable to the radicalism influence. Curiosity and trial-error behaviour make them tend to do risk-taking behaviours. If it is not accompanied by good self-control ability, it will encourage them to do actions without thinking about the impact of these actions (impulsivity). If it is not accompanied by empathy, then it tends to be behaviour that opposes and disrupts the interests of others (aggressive behaviour). This study aimed to assess the "Children of the Country" program as an effort to de-radicalize children and adolescents. Quasi experimental study was used on 30 children and adolescents in a shelter of street children in Surabaya with a pretest/post-test design. In order to measure the outcome of the program, a Radical Personality Test (RPT) was developed using big five personality construct. The increase of nationalism and positive behaviour score is not much to compensate the increase of negative radicalism score. This evaluation brings awareness to form a novel de-radicalization strategy for children and adolescents in the future.
\end{abstract}

\section{Introduction}

Street children are one of the vulnerable groups of children who are easily carried away by negative influences, including antisocial behavior which leads to radicalism. ${ }^{1}$ National Terrorism Prevention Agency or Badan Nasional Penanggulangan Terorisme (BNPT) states that radicalism is the embryo of the birth of terrorism. It has been recorded from 2010 to 2017 that there were 130 cases of terrorism in Indonesia. ${ }^{2}$ The high number of cases indicates the need for serious treatment that can be started from the basics, such as paying attention to the needs of children to grow into good personality with early education so radicalism influence can be stemmed.

Terror acts involving children and ado- lescents, such as terrorism bombs in Surabaya in May 2018 are examples of acts of terror committed by vulnerable people (in this case is children), ${ }^{3}$ who are suspected of having poor care from their parents. They grow as figures with vulnerable personalities who are easily affected by an act of terrorism. According to Sjarkawi (2008), there are two major factors that can affect personality in life; internal factors (genetic) and external factors (environment). ${ }^{4}$ This study uses shelter of street children as vulnerable genetic personality models with less supportive environment to prevent these radical potentials. This study formulates the learning program "Children of the Country" as an effort to prevent radicalism in a child and developing radical personality test as an instrument to measure radical potential in a person.

\section{Materials and Methods}

\section{Study design}

This research was a quasi-experimental study with pre/posttest design involving all residents ( 30 children) in a shelter of street children in Surabaya. "Children of the Country" program was developed as an experiential learning for residents about nationalism, spiritualism, and empathy. This program was consisted of two major activities; there were mini seminar and educational games (Table 1). Radical personality test was developed as guidance for story-telling based in-depth interview and behavior observation for children during the program (Table 2). In order to facilitate observation and measurement of behavior, thirty residents were divided into four groups according to their age. First and second group were consisted of children aged more than 12 years old (equivalent to junior and senior high school), third and fourth group were consisted of children aged less than 12 years old (equivalent to sixth grade elementary school and under). This division was not meant to observe resident based on age, but only to ease the observation. Observation was limited behavior including emotional expression (such as aggressiveness, persuasiveness, leadership, etc.) This observation was then categorized into positive and negative behavior. Each group was accompanied by an escort team. Escort teams had three main tasks; as a field guide, conducting in-depth interviews, and conducting observations during program. An escort team consisted of college students (volunteers) to avoid bias due to subjective assessments. Data was analyzed using SPSS 16.0.

This program emphasizes the formation
Correspondence: Hafid Algristian, Faculty of Medicine, Universitas Nahdlatul Ulama Surabaya, SMEA Street 57, Surabaya, Jawa Timur 60243, Indonesia.

Ph: +62.31.8291920, Fax: +62.31 .8298582$

E-mail: dr.hafid@unusa.ac.id

Key words: de-radicalization, children and adolescent, spiritualism, nationalism.

Acknowledgements: The Authors present their sincere appreciation to Universitas Nahdlatul Ulama Surabaya (UNUSA) for giving opportunity to carry out research and to Center for Religious Studies, Radicalism, and Antiterrorism (Pusat Studi Agama, Radikalisme, dan Antiterorisme-PUSARA) for giving a big data about religiosity and spirituality.

Contributions: the authors contributed equally.

Conflict of interest: the authors declare no potential conflict of interest.

Funding: Authors have received funding from Universitas Nahdlatul Ulama Surabaya (UNUSA) but declare that this research was conducted ethically and free from subjectivity.

Conference presentation: part of this paper was presented at the 3rd International Symposium of Public Health, 2018 October 31 - November 1, Universitas Airlangga, Surabaya, Indonesia.

Dedication: the article is dedicated to Universitas Nahdlatul Ulama.

Received for publication: 28 July 2019.

Revision received: 9 September 2019.

Accepted for publication: 15 October 2019.

This work is licensed under a Creative Commons Attribution NonCommercial 4.0 License (CC BY-NC 4.0).

(C) Copyright: the Author(s), 2019

Licensee PAGEPress, Italy

Journal of Public Health in Africa 2019; 10(s1):1211 doi:10.4081/jphia.2019.1211

of empathy through good teamwork. In order to support its success, this program is designed long term (more than three months) with gradual exposure according to the level of behavior change observed compared to the program target. Due to time constraints, the program is shortened to two weeks while maintaining three main values and empathy in it.

This question can be developed again according to the situation and conditions. In order to generalize measurements, the research team created a set of story-telling consisted of eight paragraphs that were read 
by the escort team. These paragraphs assessed 14 aspects which describe big five personality traits. Each paragraph has some specific expressions that must be observed. These expressions could be varying, and were needed as an analysis in the attitude and behavior observation.

\section{Results}

Residents of the shelter currently were 30 male Muslim street children under 18 years old. All is participated in this study, but only two groups in total of 16 children $(53.3 \%)$ aged $11-15$ years old were analyzed in this study. The remaining groups of children did not finish the task therefore could not be included in analysis.

Residents came from various backgrounds, such as children from poor families, children as victim of broken home family, children who were raid by officers, and children who have law problems. This shelter was developed through collaboration between Surabaya Social Service Department and Navy Marines. Physical and mental training that routinely carried out are martial arts, racing, soccer, and athletics. This activity intends to channel their mental energy into positive activities. This training also includes providing nationalism education by instilling in the love of the homeland. Spiritual and mental guidance is also carried out by religious teachers, as well as fostering interests and talents, like recitation and music training (including pop and Islamic arts).

Although there has been nationalism and spiritualism education, until now there has been no character education program for residents specifically applied to prevent radicalism. By carrying out environmental management and providing good social interaction, the influence of radicalism that leads to acts of terror can be prevented. ${ }^{5}$ The bad habits of children such as fighting among fellow residents and leaving from shelter without permission (considered as escaping, although there is no strict contract between officers and residents) but these behaviors were often resulted reports from the surrounding community about fights and theft outside the shelter by children.

The root problem in shelter is the lack of empathy education for children. They understand the importance of nationalism and spiritualism, but the aggressive behavior of fellow residents is still relatively high. They get less attention as well as the lack of affective responses that they should get from their parents or family. Shelter officers also seem to have distance with children so that attention and affection are not fully obtained by children. This attention and affection are needed to grow empathy. Therefore, this community service program is designed to make children learn and feel empathy to reduce aggressive behavior.

A preliminary study has been held to test validity and reliability of the RPT had included 36 youngsters aged 18-21 years old. There were five not valid items; all of them were items for Neuroticism (two items) and Conscientious (three items), as seen in Table 3.

This questionnaire shows high reliability with remaining nine items (Cronbach $\alpha$ $0,765)$. All items that are not valid were excluded from analysis, which all of them were in Neuroticism and Conscientiousness traits. Therefore, formula to measure radical personality became:

$$
\text { " } \mathrm{R}=\text { " (“E”)" } \div \text { “(" } \mathrm{O} \times \mathrm{A} \text { ”) }
$$

where $\mathrm{R}$ is negative radicalism, $\mathrm{E}$ is extraversion, $\mathrm{O}$ is openness to experience, and $\mathrm{A}$ is agreeableness.

The saphiro-wilk normality test (for samples $<50$ ) showed the data were not normally distributed $(\mathrm{p}<0.05)$. Wilcoxon signed rank test shows that only radicalism is significantly different between pretest and posttest scores, where posttest is higher than pretest. In other words, there was actually an increase in the value of negative radicalism after the implementation of the program for two consecutive weeks.

From Table 4, it can be seen that although it is stated not statistically significant, there has been an increase in the score of nationalism and a decrease in the score of spiritualism. This can be due to the weakness of efforts to sharpen the spiritualism

Table 1. Schedule of "Children of the Country" Program.

\begin{tabular}{|c|c|c|}
\hline Week-1 & Mini seminar & Educational games \\
\hline Monday & Learning contract \& pre-test & Group dynamics game \\
\hline Tuesday & Spiritualism: Loving God & Salat puzzle \\
\hline Wednesday & Nationalism: Long life the homeland & Bentengan (defend your land) \\
\hline Thursday & Creativity: Youth masterpiece & Eiffel Tower game \\
\hline Friday & 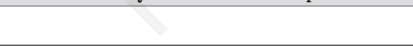 & \\
\hline
\end{tabular}

Table 2. Few questions of radical personality test.

Questions about daily activities_ Rating aspects \& details

One day your friend put his bicycle carelessly and forgot to lock it, finally the bike was stolen. He came to you sadly and told that his bicycle was gone. How were your reaction and response? (Observe expressions of disgust, ignorance, arrogant, etc.)

Your class will have a discussion about the class vacation. You propose to go to Bali because you know good places there. You believe that this idea won't disappoint them. However, your friends refuse you and plan to go to Yogyakarta.

What is your reaction? If the class voted to go to Yogyakarta, would you join them? Will you still enjoy the trip? (Observe expressions of anger, resentment, or understand, and open)

You know someone from different religion. She wants to be friends with those from same faith and clearly unjust to you even though you're sitting on the bench next to her. Sometimes you asked to borrow her book but she didn't care and didn't help you to finish your summer project.

One time, she lost her project book and would get punished if she could not make any tasks

from your teacher. She absolutely needs your help. How will you react to her?

(Observe expressions of anger, disappointment, or understand, open, etc.)
Agreeable, Neuroticism, Empathy, warm, forgiving, Mature thinking

Conscientious, openness, extravert: Rigid attitude. Openness to new experience, suggestive influencing, enthusiasm, assertiveness

Openness, agreeableness, neuroticism:

Open to difference Empathy, forgiving, warm Emotional stability 
aspects of the program. Weak method of measuring the level of spirituality in a child and adolescent is also one of the causes of false-negative measurements.

Increasing the value of negative radicalism after the implementation of the program is an interesting finding. In addition to the fact that this program was designed to deradicalize, this result was not in accordance with the findings of escort team's observations of the positive and negative behavior as shown in Table 4. In fact, there was an increase in positive behavior, but negative radicalism also increased. These different results can be viewed from the concept of a person's attitude and behavior towards a particular issue.

Attitude is the content of one's thoughts and feelings towards something that is not necessarily revealed to others, while behavior is an action that is visible and can be observed by others. ${ }^{6}$ It can be said that this negative radicalism may still be in the form of someone's attitude stored in his/her inter-

Table 3. Validity of radical personality test. ${ }^{\mathrm{a}}$

\begin{tabular}{lccc} 
Item & Aspect & r & Status \\
No. 1 & Agreeableness & $0.340^{*}$ & Valid \\
No. 2 & Neuroticism & -0.378 & Not valid \\
\hline No. 3 & Conscientious & -0.146 & Not valid \\
No. 4 & Openness to experience & $0.492^{*}$ & Valid \\
\hline No. 5 & Extraversion & $0.512^{*}$ & Valid \\
No. 6 & Agreeableness & $0.435^{*}$ & Valid \\
\hline No. 7 & Neuroticism & -0.233 & Not valid \\
No. 8 & Agreeableness & $0.386^{*}$ & Valid \\
\hline No. 9 & Extraversion & $0.626^{*}$ & Valid \\
No. 10 & Conscientious & -0.064 & Not valid \\
\hline No. 11 & Openness to experience & $0.617^{*}$ & Valid \\
No. 12 & Extraversion & $0.670^{*}$ & Valid \\
\hline No. 13 & Openness to experience & $0.533^{*}$ & Valid \\
No. 14 & Conscientious & 0.108 & Not valid \\
\hline
\end{tabular}

aPreliminary study, $n=40$, item-total item correlation. ${ }^{*}$ Significant $(p<0.05) . r=$ Pearson coefficient.

Table 4. Comparison of pre-test and pos-ttest scores.

\begin{tabular}{lccc} 
& Pre-test $(\chi \pm S D)$ & Post-test $(\chi \pm S D)$ & Wilcoxon $(p)^{\mathrm{a}}$ \\
Nationalism & $3.375 \pm 0.719$ & $3.500 \pm 0.632$ & 0.589 \\
Spiritualism & $3.438 \pm 0.727$ & $3.375 \pm 0.806$ & 1.000 \\
\hline Radicalism & $0.207 \pm 0.060$ & $0.314 \pm 0.199$ & 0.039 \\
Positive behaviour & $1.291 \pm 0.334$ & $1.407 \pm 0.219$ & 0.088 \\
\hline Negative behaviour & $1.057 \pm 0.416$ & $1.095 \pm 0.554$ & 0.877 \\
\hline
\end{tabular}

aWilcoxon signed rank test, significant if $p<0.05$

Table 5. Comparison of pre-test and post-test scores on radical personality test.

\begin{tabular}{lccc} 
& Pre-test $(x \pm S D)$ & Post-test $(x \pm S D)$ & Wilcoxon $(p)^{a}$ \\
Extraversion & $2.016 \pm 0.496$ & $2.813 \pm 0.788$ & 0.001 \\
Openness & $3.062 \pm 0.781$ & $3.125 \pm 0.739$ & 0.693 \\
\hline Agreeableness & $3.365 \pm 0.495$ & $3.396 \pm 0.937$ & 0.753 \\
\hline
\end{tabular}

aWilcoxon signed rank test, significant if $p<0.05$ nal world, which may be different from the havior revealed. It can be concluded that versa. Table 5 shows that all aspects have mentation of the program. Extraversion correlated with assertive behavior; the ability to opinion and defend his/her position. This trait is also related to group domination and the ability to influence others. In conflict management, individuals with high makes the ism seem biased. Although this program is the openness and agreeableof a person, it has not been enough to compensate for the increase in extraversion.

\section{Discussion}

One of the difficulties in implementing a de-radicalization program is the difference between sincere intentions and the obligation to obey the rules. Some research shows that without the personal motivation of the perpetrator, the program will not work. ${ }^{8}$ This personal motivation generally begins with small differences in views in groups, which can be tolerated initially, but the longer it will lead to friction and estrangement between members. This process is called "disengagement". ${ }^{9}$ One of the ways of disengagement is to offer an alternative way of life that can still be tolerated for both parties, between perpetrator (who had some estrangement with his/her group) and government or any de-radicalization institute. This way of life is expected to touch the emotional side of the perpetrator, so that they can voluntarily leave the group. Touching the emotional side is needed to do the process of disillusionment with the perpetrator. The alternative lifestyle if offered in a very persuasive way will help the tenuous member to start doubting the jargon that his group echoed. ${ }^{10}$

Unfortunately, this program did not address the children's emotion carefully. This research was assuming that aggressive behavior was a result of less empathy in the first place. By increasing empathy, aggressive behavior would be lessened and providing the good environment for children support. This assumption then proved otherwise. Studies show that the jargon of negative radicalism is actually "marketed" through melancholic narratives that touch someone's empathy. By utilizing empathy, jargon such as injustice and compassion towards oppressed brothers becomes popular. It is very easily accepted without having to be filtered through a person's critical analysis. ${ }^{11,12}$ On the other hand, this research initially focused on solving the problems of aggressiveness which are the seeds of radicalism. The high aggressive behavior of the residents was also assumed to occur even though they had received nationalism and spiritualism education before. This program is intended to change this aggressive behavior. In escort team observation, there is indeed an increase in the value of positive behavior, but negative radicalism also increases. This finding also strengthens the fact that although radicalism can be eradicated, this spirit of radicalism is still stored in the minds of its adherents. This assumption is debatable, and requires further research in the future. 


\section{Conclusions}

The de-radicalism program must include disillusionment as a cognitive aspect and disengagement as an affective aspect, thus increasing the chances of antiterror behavior in children consistently. This evaluation brings awareness to form a novel de-radicalization strategy for children and adolescents in the future.

\section{References}

1. Krug EG, Dahlberg LL, Mercy JA, et al. World report on violence and health. Geneva: WHO; 2002.

2. Fakultas Ilmu Sosial dan Ilmu Politik Universitas Indonesia. Menelaah Tren Terorisme di Indonesia dari Masa ke Masa dan Cara Penanganannya 2018. Available from: http:/fisip.ui.ac.id/menelaah-tren-terorisme-di-indonesia-dari-masa-ke-masadan-cara-penanganannya/. Accessed on:
15 August 2018

3. Marcoes L. Bagaimana para perempuan menjadi pelaku teror dan membawa anak? - BBC News Indonesia 2018. Available from: https://www.bbc.com/indonesia/indone sia-44106870. Accessed on: 24 October 2018.

4. Sjarkawi. Pembentukan Kepribadian Anak: peran moral, intelektual, emosional, dan sosial sebagai wujud integritas membangun jati diri. Jakarta: Bumi Aksara; 2008.

5. Kraus SJ. Attitudes and the Prediction of Behavior: A Meta-Analysis of the Empirical Literature. Personal. Soc. Psychol. Bull. 1995;21(1):58-75.

6. Kammrath LK, McCarthy MH, Cortes $\mathrm{K}$, et al. Picking One's Battles: How Assertiveness and Unassertiveness Abilities Are Associated With Extraversion and Agreeableness. Soc. Psychol. Personal. Sci. 2015;6(6):622629.

7. John H, Braddock K. Rehabilitating the terrorists?: Challenges in assessing the effectiveness of de-radicalization programs. Terror. Polit. Violence 2010;22(2):267-291.

8. Altier MB, Boyle EL, Shortland ND, et al. Why they leave: An analysis of terrorist disengagement events from eighty-seven autobiographical accounts. Secur. Stud. 2017;26(2):305332.

9. Reinares F. Exit from terrorism: A qualitative empirical study on disengagement and deradicalization among members of ETA. Terror. Polit. Violence 2011;23(5):780-803.

10. Hasani I, Naipospos BT. Dari Radikalisme Menuju Terorisme. Jakarta: Pustaka Masyarakat Setara; 2012.

11. Algristian H. Apakah Radikalisme Akar Terorisme. Duta Masyarakat 2018. Surabaya: Duta Masyarakat; 2018.

12. Algristian H. Kontra-Terorisme: Seandainya Dunia Tanpa Islam. Surabaya: Duta Masyarakat; 2018. 